\section{The hypertriglyceridemic waist phenotype in young adults from the Southern Region of Brazil}

\author{
Cintura hipertrigliceridêmica em adultos jovens no \\ Sul do Brasil
}

\author{
Cintura hipertrigliceridémica en adultos jóvenes en \\ el sur de Brasil
}

\author{
${ }_{1}$ Universidade Federal de \\ Pelotas, Pelotas, Brasil. \\ Correspondence \\ R. L. Haack \\ Universidade Federal de \\ Pelotas. \\ Rua Marechal Deodoro 1160 \\ 3o piso, Pelotas, RS \\ 96020-220, Brasil. \\ ricardohaack@yahoo.com.br
}

\begin{abstract}
The present study aimed to assess the prevalence of the hypertriglyceridemic waist phenotype and its associated factors among subjects that have been followed up from birth. In 1982, all maternity hospitals in the city of Pelotas, in the Southern Region of Brazil, were visited and all births were recorded. Babies whose parents lived in the urban area of Pelotas were subsequently followed up on several occasions. A 22 to 23-year follow-up of this birth cohort was carried out in 2004 and 2005. The presence of the hypertriglyceridemic waist phenotype was defined as waist circumference $\geq 90 \mathrm{~cm}$ and triglyceride levels $\geq$ $177 \mathrm{mg} / \mathrm{dL}$ for males, and waist circumference $\geq$ $85 \mathrm{~cm}$ and triglyceride levels $\geq 133 \mathrm{mg} / \mathrm{dL}$ for females. The prevalence of the hypertriglyceridemic waist phenotype was $5.9 \%$ and $4.5 \%$ among men and women, respectively. Among males, a sedentary lifestyle during leisure time, smoking and obesity were associated with the presence of the hypertriglyceridemic waist phenotype, whereas among females the condition was positively associated with skin color, family income, obesity and dietary fat intake.
\end{abstract}

Waist Circumference; Abdominal Obesity; Triglycerides
Ricardo Lanzetta Haack ${ }^{1}$ Bernardo Lessa Horta 1 Denise Petrucci Gigante 1 Fernando C. Barros 1 Isabel Oliveira 1 Vera M. Silveira 1

\section{Resumo}

O presente estudo teve como objetivo determinar a prevalência do fenótipo da cintura hipertrigliceridêmica e seus fatores associados entre indivíduos que foram seguidos desde o nascimento. Em 1982, as maternidades de Pelotas, sul do Brasil, foram visitadas e todos os nascimentos foram identificados. Em 2004-2005, buscou-se acompanhar toda a coorte. A presença de fenótipo da cintura hipertrigliceridêmica foi definida como circunferência da cintura $\geq 90 \mathrm{~cm}$ e triglicerídeos $\geq 177 \mathrm{mg} /$ dL para o sexo masculino, $e$ circunferência da cintura $\geq 85 \mathrm{~cm}$ e triglicerídeos $\geq 133 \mathrm{mg} / \mathrm{dL}$ para as mulheres. A prevalência de fenótipo da cintura hipertrigliceridêmica foi de $5,9 \%$ e 4,5\% entre os homens e mulheres, respectivamente. Para os homens, o sedentarismo no lazer, tabagismo e obesidade estiveram associados com fenótipo da cintura hipertrigliceridêmica. Por outro lado, entre as mulheres, fenótipo da cintura hipertrigliceridêmica foi positivamente associado com a cor da pele, renda familiar, obesidade e consumo de gordura.

Circunferência da Cintura; Obesidade Abdominal; Triglicerídeos 


\section{Introduction}

Chronic non-communicable diseases, such as cardiovascular disorders, cancer and diabetes are the leading causes of mortality worldwide, accounting for approximately $60 \%$ of all deaths 1,2 . In the United States, the American Cardiology Association estimates that more than one in three adults have some form of cardiovascular disease 3 .

In 2000, Lemieux et al. 4 reported that adults with increased waist circumference and high plasma triglyceride levels were more likely to present metabolic markers of cardiovascular risk and called this association the hypertriglyceridemic waist phenotype. Several studies have reported that this condition is associated with the cardiometabolic risk profile (higher levels of insulin, Apolipoprotein B, C-reactive protein and small dense LDL cholesterol) as well an increased risk of coronary artery disease 4,5,6,7,8,9,10. Studies have identified the following factors related to the presence of hypertriglyceridemic waist phenotype: sedentary lifestyle 11,12,13, obesity 9,11,14 lower levels of schooling 11,13, and low intake of grains 15 . However, despite the marked association between cardiovascular disease and metabolic risk factors, few studies have evaluated the risk factors for hypertriglyceridemic waist phenotype, especially in young adults.

This study aimed to assess the prevalence of hypertriglyceridemic waist phenotype and its association with skin color, family income, smoking, sedentary lifestyle, fat consumption and fiber intake among 23-year-olds from a city in the Southern Region of Brazil.

\section{Methods}

During 1982, all maternity hospitals in the city of Pelotas were visited on a daily basis and 7,392 births were recorded. Those babies whose parents lived in the urban area of Pelotas $(\mathrm{N}=5,914)$ were examined and have been followed up on several occasions. Further details regarding study methodology have been described elsewhere 16 .

A 22 to 23-year follow-up of this birth cohort was carried out between October 2004 and August 2005. The subjects that were located answered a questionnaire and were examined and asked to donate a blood sample collected by venipuncture.

The presence of hypertriglyceridemic waist phenotype was defined as waist circumference $\geq 90 \mathrm{~cm}$ and triglycerides $\geq 177 \mathrm{mg} / \mathrm{dL}$ for males, and waist circumference $\geq 85 \mathrm{~cm}$ and triglycerides $\geq 133 \mathrm{mg} / \mathrm{dL}$ for females $4,14,17$. Waist circumfer- ence was measured using a fiberglass tape (Cardiomed, $1 \mathrm{~mm}$ precision, Curitiba, Brazil), halfway between the iliac crest and last costal arch. Pregnant women or those who had had children in the last six months were excluded. Triglyceride levels were assessed using the colorimetric enzymatic method.

The following metabolic cardiovascular risk factors were measured:

- Blood pressure was measured at the beginning and at the end of the interview using a calibrated digital wrist blood pressure monitor (Omron HEM-629, Kyoto, Japan) on the left arm. Before each measurement the individual should sat rest for at least five minutes. Mean arterial pressure was estimated as $2 / 3$ mean diastolic blood pressure plus 1/3 mean systolic blood pressure.

- Random blood glucose was assessed from blood drawn from the fingertip using a portable glucose meter (Accu-Check Advantage, Roche, Indianapolis, USA). Since glucose levels are related to fasting time, glucose estimates were corrected for the time elapsed since the last meal 18 . - HDL cholesterol was measured with a Selectra 2 analyzer (Merck, Darmstadt, Germany) using an ultra sensitive direct method.

- High-sensitivity C-reactive protein (hs-CRP) was measured using the chemiluminescent immunoassay system (Siemens, DPC Immulite 2500, Los Angeles, USA). Measurements below the lower detection limit of $0.1 \mathrm{mg} / \mathrm{L}$ were converted to $0.05 \mathrm{mg} / \mathrm{L}$. Subjects with hs-CRP > $10 \mathrm{mg} / \mathrm{L}$, pregnant women and those using oral contraceptives were excluded from the hs-CRP analysis.

The following socioeconomic, demographic and behavioral characteristics were also assessed as possible risk factors:

- Self-reported skin color;

- Family income in adulthood;

- Leisure-time physical activity: a score representing weekly physical activity based on the sum of time spent walking and on moderate physical activity and time spent on vigorous activities multiplied by two was calculated using the long version of the previously validated International Physical Activity Questionnaire (IPAQ) 19. Subjects with a score of less than 150 minutes were classified as sedentary;

- Tobacco smoking: subjects who smoked at least one cigarette per day were considered as smokers;

- High fat and low fiber diet: dietary pattern in the preceding 12 months was evaluated using the Block Questionnaire, which includes 24 scored items regarding the weekly consumption of each food. Individuals who scored less than 20 points were considered as having a low dietary 
fiber intake and those who scored 25 points and above were considered as having a high dietary fat intake 20 .

Triglycerides and hs-CRP values were asymmetrically distributed and a natural log transformation was performed with these variables and results are given as the back-transformed geometric means.

A sex-stratified statistical analysis was performed using the software Stata 12.0 (Stata Corp., College Station, USA). Chi-square test with Yates correction for $2 \mathrm{x} 2$ tables was used to test comparisons between proportions and analysis of variance was used to compare means. Multivariate analysis was performed using Poisson regression with robust adjustment of variance based on the hierarchical model shown in Figure 1.

In order to assess whether the presence of enlarged waist and hypertriglyceridemia was related to higher values of cardiovascular risk factors, an interaction term was included in the analysis of the association between waist circumference and triglyceride levels and cardiovascular risk factors.

The study was approved by the Ethical Review Board of the Faculty of Medicine of the Pelotas Federal University, and written informed consent was obtained from participating subjects.

\section{Results}

A total of 4,297 subjects were interviewed between October 2004 and August 2005. After taking into account 282 recorded deaths, this number corresponds to a follow-up rate of $77.4 \%$.

Table 1 shows that approximately $75 \%$ of the sample was white. Prevalence of overweight and obesity was $23.1 \%$ and $7.5 \%$ among men and $17.9 \%$ and $9.1 \%$ among women, respectively. Table 1 also shows the mean values for triglyceride levels, HDL cholesterol, non-fasting blood glucose, high-sensitivity C-reactive protein and blood pressure for men and women. Prevalence of the hypertriglyceridemic waist phenotype among men and women was $5.9 \%$ and $4.5 \%$, respectively. Furthermore, $69.9 \%$ of men and $68.6 \%$ of women had a low dietary fiber intake and $54.8 \%$ of men and $45.4 \%$ of women had a high dietary fat intake. Approximately $25 \%$ of the sample was smokers and $80 \%$ of women and $50 \%$ of men were sedentary during leisure time.

Table 2 shows that HDL cholesterol levels were higher and blood pressure, non-fasting blood glucose and body mass index were lower, in individuals with normal waist circumference and triglyceride levels. The presence of hypertriglyceridemia, or enlarged waist circumference, was associated with slight changes in metabolic cardiovascular risk factors, lower HDL cholesterol and higher blood pressure and hs-CRP. The test of interaction between hypertriglyceridemia and each of the cardiovascular metabolic risk factors was statistically significant suggesting that the presence of the phenotype accentuates metabolic cardiovascular risk factors.

Tables 3 and 4 present the prevalence, prevalence ratio and adjusted prevalence ratio of the hypertriglyceridemic waist phenotype according to sample characteristics by gender. With respect to males, being sedentary during leisure time, smoking and obesity was associated with the hypertriglyceridemic waist phenotype, whereas among females the condition was positively associated with skin color, family income, fat consumption and body mass index.

\begin{tabular}{|c|c|c|c|}
\hline \multicolumn{2}{|c|}{ Skin color } & \multicolumn{2}{|c|}{ Family income } \\
\hline Smoking & Fat consumption & Fiber consumption & Sedentary during leisure time \\
\hline \multicolumn{4}{|c|}{ BMI } \\
\hline \multicolumn{4}{|c|}{ Hypertriglyceridemic waist phenotype } \\
\hline
\end{tabular}

BMI: body mass index. 
Table 1

Key characteristics of the study sample.

\begin{tabular}{|c|c|c|}
\hline Sample characteristics & Male & Female \\
\hline \multicolumn{3}{|l|}{ Skin color [n (\%)] } \\
\hline White & $1,658(74.9)$ & $1,580(75.9)$ \\
\hline Non white & $555(25.1)$ & $503(24.2)$ \\
\hline \multicolumn{3}{|l|}{ Family income (tertiles) [mean $\mathrm{R} \$(\mathrm{SD})]$} \\
\hline 1 st & $463.2(171.2)$ & $443.8(179.8)$ \\
\hline $2^{\text {nd }}$ & $1,054.3(206.3)$ & $1,046.1(205.6)$ \\
\hline 3 rd & $3,170.8(2,696.4)$ & $3,189.6(2,518.4)$ \\
\hline \multicolumn{3}{|l|}{ Body mass index $\left(\mathrm{kg} / \mathrm{m}^{2}\right)$ [n (\%)] } \\
\hline$<18.5$ & $107(4.9)$ & $150(7.2)$ \\
\hline $18.5-24.9$ & $1,424(64.6)$ & $1,370(65.8)$ \\
\hline $25.0-29.9$ & $509(23.1)$ & $372(17.9)$ \\
\hline$\geq 30.0$ & $166(7.5)$ & $190(9.1)$ \\
\hline Sedentary during leisure time [n (\%)] & $1,091(49.3)$ & $1,676(80.5)$ \\
\hline Smoking [n (\%)] & $611(27.6)$ & $492(23.6)$ \\
\hline Triglycerides (mmol/l) [geometric mean (SD)] & $1,00(1.78)$ & $1,03(1.62)$ \\
\hline Waist circumference $(\mathrm{cm})$ [mean (SD)] & $80,9(10.1)$ & $75,6(11.1)$ \\
\hline HDL cholesterol (mg/dL) [mean (SD)] & $51,6(11.2)$ & $59,4(13.5)$ \\
\hline Non-fasting glucose (mg/dL) [mean (SD)] & $99,8(15.6)$ & $94,8(14.1)$ \\
\hline Hs-CRP (mg/dL) [geometric mean (SD)] & $0,78(3.17)$ & $1,31(3.33)$ \\
\hline Mean arterial blood pressure $(\mathrm{mmHg})[$ mean $(\mathrm{SD})]$ & $91,6(11.9)$ & $84,6(11.1)$ \\
\hline Hypertriglyceridemic waist phenotype [n (\%)] & $113(5.9)$ & $80(4.5)$ \\
\hline
\end{tabular}

Table 2

Biological cardiovascular risk factors and the hypertriglyceridemic waist phenotype.

\begin{tabular}{|c|c|c|c|c|c|}
\hline & \multicolumn{4}{|c|}{ Hypertriglyceridemic waist phenotype [mean $(95 \% \mathrm{Cl})]$} & \multirow{2}{*}{$\begin{array}{l}\mathrm{p} \text {-value of } \\
\text { interaction }\end{array}$} \\
\hline & No & Only hypertriglyceridemia & $\begin{array}{l}\text { Only enlarged } \\
\text { waist }\end{array}$ & $\begin{array}{l}\text { Hypertriglyceridemic waist } \\
\text { phenotype }\end{array}$ & \\
\hline HDL cholesterol (mg/dL) & $56.0(55.5 ; 56.5)$ & $55.2(53.7 ; 56.6)$ & $53.0(51.7 ; 54.3)$ & $48.9(47.3 ; 50.6)$ & 0.02 \\
\hline Non-fasting blood glucose (mg/dL) & $96.8(96.3 ; 97.4)$ & $98.5(97.0 ; 100.1)$ & $98.9(97.3 ; 100.5)$ & $101.5(99.6 ; 103.5)$ & 0.50 \\
\hline Mean blood pressure $(\mathrm{mmHg})$ & $87.1(86.7 ; 87.5)$ & $88.6(87.5 ; 89.8)$ & $91.9(90.6 ; 93.3)$ & $97.9(96.2 ; 99.5)$ & $<0.00$ \\
\hline $\mathrm{Hs}-\mathrm{CRP}(\mathrm{mg} / \mathrm{dL})$ & $0.82(0.78 ; 0.86)$ & $1.26(1.17 ; 1.42)$ & $1.72(1.52 ; 1.93)$ & $2.03(1.79 ; 2.34)$ & 0.06 \\
\hline $\mathrm{BMI}\left(\mathrm{kg} / \mathrm{m}^{2}\right)$ & $22.2(22.1 ; 22.3)$ & $23.2(22.9 ; 23.4)$ & $30.5(30.0 ; 30.9)$ & $31.7(31.1 ; 32.3)$ & $<0.00$ \\
\hline Total [N (\%)] & $2,745(74.6)$ & $376(10.2)$ & $368(10.0)$ & $193(5.2)$ & \\
\hline
\end{tabular}

BMI: body mass index; $95 \% \mathrm{Cl}: 95 \%$ confidence interval.

\section{Discussion}

The present study may be considered a crosssectional analysis because we only analyzed data gathered in the 2004/2005 follow-up visit of 1982 Pelotas birth cohort

With regard to the limitations of this study, it is important to mention that the measurement of food consumption is a significantly challenging task and the instrument used has not yet been formally validated for use with the Brazilian population. However, it should be noted that more complex methods of measuring food frequency were tested and showed similar results to the Block Questionnaire 20.

Another important limitation is that, despite being a nested cohort study with good information on confounders, cross-sectional studies are vulnerable to reverse causality. 
Prevalence, prevalence ratio and adjusted prevalence ratio of the hypertriglyceridemic waist phenotype by sample characteristics (males)

\begin{tabular}{|c|c|c|c|c|}
\hline Characteristics & $\mathrm{n}$ & p-value (\%) & PR $(95 \% \mathrm{Cl})$ & $P R *(95 \% C l)$ \\
\hline Skin color & & $p=0.13$ & $p=0.13$ & $p=0.21$ \\
\hline White & 1,425 & 6.4 & 1.00 & 1.00 \\
\hline Non-white & 489 & 4.5 & $0.70(0.45 ; 1.11)$ & $0.74(0.45 ; 1.18)$ \\
\hline Family income (tertiles) & & $p=0.23$ & $p=0.23$ & $p=0.35$ \\
\hline 1 st & 605 & 5.0 & $0.70(0.45 ; 1.08)$ & $0.80(0.53 ; 1.23)$ \\
\hline $2^{\text {nd }}$ & 650 & 5.5 & $0.78(0.51 ; 1.18)$ & $0.73(0.46 ; 1.15)$ \\
\hline 3 rd & 659 & 7.1 & 1.00 & 1.00 \\
\hline Smoking & & $p=0.06$ & $p=0.07$ & $p=0.05$ \\
\hline No & 1,378 & 6.5 & 1.00 & 1.00 \\
\hline Yes & 536 & 4.3 & $0.66(0.42 ; 1.03)$ & $0.65(0.41 ; 1.01)$ \\
\hline Sedentary lifestyle during leisure time & & $p=0.05$ & $p=0.05$ & $p=0.03$ \\
\hline No & 967 & 4.9 & 1.00 & 1.00 \\
\hline Yes & 947 & 7.0 & $1.43(1.00 ; 2.06)$ & $1.49(1.03 ; 2.14)$ \\
\hline Fat score (g) & & $p=0.50$ & $p=0.50$ & $p=0.51$ \\
\hline$<25$ & 48 & 5.5 & 1.00 & 1.00 \\
\hline$\geq 25$ & 65 & 6.2 & $1.13(0.79 ; 1.63)$ & $1.14(0.78 ; 1.69)$ \\
\hline Fiber score (g) & & $p=0.55$ & $p=0.55$ & $p=0.49$ \\
\hline$<20$ & 1,335 & 5.7 & 1.00 & 1.00 \\
\hline$\geq 20-29$ & 579 & 6.4 & $1.12(0.77 ; 1.64)$ & $1.15(0.78 ; 1.69)$ \\
\hline BMI $\left(\mathrm{kg} / \mathrm{m}^{2}\right)$ & & $p<0.00$ & $p<0.00$ & $p<0.00$ \\
\hline$<25.0$ & 3 & 0.2 & 1.00 & 1.00 \\
\hline $25.0-29.9$ & 40 & 9.0 & $39.90(12.40 ; 128.50)$ & $39.91(12.32 ; 129.32)$ \\
\hline$\geq 30.0$ & 70 & 48.6 & $215.00(68.60 ; 674.40)$ & $209.53(66.58 ; 659.38)$ \\
\hline
\end{tabular}

* Adjusted for variables of the same level and upper level.

BMI: body mass index; PR: prevalence ratio; $95 \% \mathrm{Cl}$ : $95 \%$ confidence interval.

Recent studies indicate that the atherosclerosis process starts at an early age and is linked to obesity and other components of the metabolic syndrome during childhood 21 . The identification of asymptomatic individuals at high risk of coronary heart disease and diabetes has important public health implications for prevention of cardiovascular diseases, given the increased incidence of these diseases 22 . The prevalence of the hypertriglyceridemic waist phenotype was $5.9 \%$ among males and $4.5 \%$ among females and its presence was associated with a higher level of metabolic cardiovascular risk. A number of authors 8,9,10,14,23,24,25,26,27, including Lemieux et al. 4,5 and Hiura et al. 7, have also reported such an association, demonstrating that the hypertriglyceridemic waist phenotype is an important marker of cardiovascular risk.

Studies show that the prevalence of this phenotype among adults of both sexes ranges from 12.7 to $36.5 \% 10,13,17,27$. In 2003, Kahn observed a prevalence rate of $24.8 \%$ among a sample of adults aged 18 to 90 years in the United States; the same study found that prevalence was lowest (6.2\%) among the 18 to 24 year age group 23. Prevalence among healthy adults in Israel, the Netherlands and Spain was $12.7 \%, 31 \%$ and $14.5 \%$, respectively $13,17,27$. A study of a sample of 14,770 adults aged between 35 and 74 years carried out in China by Yu et al. 28 in 2010 showed that the hypertriglyceridemic waist phenotype was present in $35.4 \%$ of men and $33.6 \%$ of women. Prevalence was $9.6 \%$ among men and $23.6 \%$ among women in a study of Iranians aged between 30 and 55 years 29 .

Although research involving young people is rare, two studies conducted with adolescents in Iran in 2006 and 2008 reported prevalence rates of $6.4 \% 30$ and $8.5 \% 11$, respectively.

In the present study, individuals with the hypertriglyceridemic waist phenotype had lower HDL cholesterol and higher mean blood pressure, non fasting blood glucose levels and hs-CRP levels than those with normal waist circumfer- 
Prevalence, prevalence ratio and adjusted prevalence ratio of the hypertriglyceridemic waist phenotype by sample characteristics (females).

\begin{tabular}{|c|c|c|c|c|}
\hline Characteristics & $\mathrm{n}$ & p-value (\%) & PR $(95 \% \mathrm{Cl})$ & $P R *(95 \% C l)$ \\
\hline Skin color & & $p=0.04$ & $p=0.05$ & $p=0.01$ \\
\hline White & 1,333 & 5.1 & 1.00 & 1.00 \\
\hline Non-white & 435 & 2.8 & $0.54(0.30 ; 0.99)$ & $0.45(0.25 ; 0.82)$ \\
\hline Family income (tertiles) & & $p=0.00$ & $p=0.00$ & $p<0.00$ \\
\hline $1 \mathrm{st}$ & 642 & 6.5 & $2.73(1.48 ; 5.03)$ & $1.92(0.99 ; 3.73)$ \\
\hline $2^{\text {nd }}$ & 584 & 4.3 & $1.78(0.92 ; 3.45)$ & $3.11(1.69 ; 5.74)$ \\
\hline $3 \mathrm{rd}$ & 542 & 2.4 & 1.00 & 1.00 \\
\hline Smoking & & $p=0.78$ & $p=0.78$ & $p=0.88$ \\
\hline No & 1,349 & 4.5 & 1.00 & 1.00 \\
\hline Yes & 419 & 4.8 & $1.07(0.65 ; 1.76)$ & $0.96(0.59 ; 1.58)$ \\
\hline Sedentary lifestyle during leisure time & & $p=0.24$ & $p=0.24$ & $p=0.51$ \\
\hline No & 357 & 3.4 & 1.00 & 1.00 \\
\hline Yes & 1,411 & 4.8 & $1.43(0.78 ; 2.61)$ & $1.23(0.67 ; 2.24)$ \\
\hline Fat score (g) & & $p=0.00$ & $p=0.00$ & $p=0.01$ \\
\hline$<25$ & 57 & 5.9 & 1.00 & 1.00 \\
\hline$\geq 25$ & 23 & 2.8 & $0.48(0.30 ; 0.77)$ & $0.52(0.32 ; 0.85)$ \\
\hline Fiber score (g) & & $p=0.47$ & $p=0.47$ & $p=0.24$ \\
\hline$<20$ & 1,214 & 4.3 & 1.00 & 1.00 \\
\hline$\geq 20-29$ & 554 & 5.1 & $1.18(0.75 ; 1.85)$ & $1.31(0.84 ; 2.05)$ \\
\hline BMI $\left(\mathrm{kg} / \mathrm{m}^{2}\right)$ & & $p<0.00$ & $p<0.00$ & $p<0.00$ \\
\hline$<25.0$ & 5 & 0.4 & 1.00 & 1.00 \\
\hline $25.0-29.9$ & 23 & 7.5 & $19.50(7.50 ; 50.90)$ & $20.18(7.67 ; 53.08)$ \\
\hline$\geq 30.0$ & 52 & 33.8 & $88.20(35.80 ; 217.50)$ & $87.74(34.69 ; 221.92)$ \\
\hline
\end{tabular}

* Adjusted for variables of the same level and upper level.

BMI: body mass index; PR: prevalence ratio; $95 \% \mathrm{Cl}$ : $95 \%$ confidence interval.

ence and triglyceride levels. Similar findings have been reported in another studies 5,6,7,8,9,10,12,13,14, $17,23,24,25,26,27,31,32$, suggesting that the presence of an enlarged waist and increased triglyceride levels is related to metabolic cardiovascular risk factors. Therefore, the presence of the hypertriglyceridemic waist phenotype should be considered a marker for the presence of cardiovascular disease risk factors.

A sedentary lifestyle during leisure time, smoking and obesity were factors associated with the presence of the hypertriglyceridemic waist phenotype in males. Three other studies have also reported that a sedentary lifestyle increases the prevalence of the hypertriglyceridemic waist phenotype $11,12,13$. In females, a sedentary lifestyle during leisure time was also associated with an increase in the prevalence of the condition but the association was not statistically significant. The variables associated with the presence of the hypertriglyceridemic waist phenotype in women were white skin color, low family income, low dietary fat intake and obesity.
We also found that physical activity had a protective effect even among obese individuals.

Studies involving adults aged between 45 and 79 years have reported that obesity is related to the presence of the hypertriglyceridemic waist phenotype $9,11,14,30$. We also observed that body mass index was positively related to prevalence of the hypertriglyceridemic waist phenotype which was present in four in every ten obese individuals included in this study. This indicates that, even among young adults, there is a direct relationship between obesity and a higher risk of carrying a phenotype that is strongly related to the presence of atherogenic risk factors, thus reinforcing the need to prevent obesity at an early age.

Other studies have reported that low socioeconomic status is related to a higher risk of the presence of the hypertriglyceridemic waist phenotype 11,13 . The present study observed that the association between income and prevalence of the condition is positive among males and a negative among females. A previous study 33 posed the hypothesis that poorer women have 
more children and therefore a larger waist circumference; however, even after controlling for socioeconomic status, this factor was still associated with the presence of the phenotype in women. On the other hand, the association vanished after controlling for obesity and overweight. Therefore, the association between low socioeconomic status and presence of the hypertriglyceridemic waist phenotype is mediated by overweight/obesity.

Esmaillzadeh et al. 15 reported that a higher consumption of refined grains was associated with higher prevalence of the hypertriglyceridemic waist phenotype, and Alavian et al. 11 showed that the risk of the presence of the hypertriglyceridemic waist phenotype rose with the consumption of solid hydrogenated fat and white bread. Given these findings, an inverse association is unlikely. One possible explanation is that our analysis is cross-sectional, and therefore susceptible to reverse causality bias. Among females, for example, low dietary fat intake is also positively associated with overweight and obesity. However, given that they are overweight or obese it is possible that these individuals have a low dietary fat intake because they are dieting.
On the other hand, a longitudinal analysis of a subset of 19-year-old girls found that the risk of the presence of the hypertriglyceridemic waist phenotype was not dependent on dietary fat intake $(\mathrm{p}=0.57)$.

Smoking is a well-known cardiovascular risk factor and its association with other factors continues to be a subject of research. In our study, smoking was inversely associated with the presence of the hypertriglyceridemic waist phenotype among men; with a prevalence of $6.5 \%$ among smokers compared to $4.3 \%$ in nonsmokers ( $\mathrm{p}=$ 0.06 ). In this study, $18.2 \%$ of male smokers were overweight, compared to $25 \%$ of nonsmokers, and $5.9 \%$ were obese, compared to $8.2 \%$ of nonsmokers $(p<0.05)$. No significant differences were found between triglyceride levels between smokers and nonsmokers.

In conclusion, prevalence of the hypertriglyceridemic waist phenotype among young adults is strongly associated with cardiovascular risk factors. The association between waist circumference and triglyceride levels seems to be a good and cost effective method and less invasive alternative for screening individuals at risk of developing cardiovascular disease.

\section{Resumen}

El presente estudio tuvo como objetivo determinar la prevalencia del fenotipo de la cintura hipertrigliceridémica y sus factores asociados entre individuos que fueron observados desde su nacimiento. En 1982, las maternidades de Pelotas, sur de Brasil, fueron visitadas y todos los nacimientos fueron identificados. En 20042005, se decidió realizar un seguimiento de toda la cohorte. La presencia del fenotipo de la cintura hipertrigliceridémica se definió como una circunferencia de la cintura $\geq 90 \mathrm{~cm}$ y triglicéridos $\geq 177 \mathrm{mg} / \mathrm{dL}$ para el sexo masculino y circunferencia de la cintura $\geq 85 \mathrm{~cm}$ y triglicéridos $\geq 133 \mathrm{mg} / \mathrm{dL}$ para las mujeres. La prevalencia del fenotipo de la cintura hipertrigliceridémica fue de un 5,9\% y un 4,5\% entre los hombres y mujeres, respectivamente. Para los hombres, el sedentarismo en el ocio, tabaquismo y obesidad estuvo asociado con el fenotipo de la cintura hipertrigliceridémica. Por otro lado, entre las mujeres, el fenotipo de la cintura hipertrigliceridémica fue positivamente asociado con el color de la piel, renta familiar, obesidad y consumo de grasa.

Circunferencia de la Cintura; Obesidad Abdominal; Triglicéridos 


\section{Contributors}

R. L. Haack contributed to study design, data analysis and interpretation and to drafting and approval of the final version of this paper. B. L. Horta contributed to study design and to drafting and approval of the final version of this paper. D. P. Gigante, F. C. Barros, I. Oliveira and V. M. Silveira contributed to study design, critical review and approval of the final version of this paper.

\section{Acknowledgments}

The 1982 birth cohort study is currently supported by the Wellcome Trust initiative entitled Major Awards for Latin America on Health Consequences of Population Change. Previous phases of the study were supported by the International Development Research Center, The World Health Organization, Overseas Development Administration, European Union, PRONEX, CNPq and Brazilian Ministry of Health.

\section{References}

1. Murray CLJ, Lopez AD. The global burden of disease: a comprehensive assessment of mortality and disability from diseases, injuries, and risk factors in 1990 and projected to 2020. Boston: Harvard School of Public Health; 1996.

2. Blackburn P, Lamarche B, Couillard C, Pascot A Bergeron N, Prud'Homme D, et al. Postprandial hyperlipidemia: another correlate of the "hypertriglyceridemic waist" phenotype in men. Atherosclerosis 2003; 171:327-36.

3. Roger VL, Go AS, Lloyd-Jones DM, Adams RJ, Berry JD, Brown TM, et al. Heart disease and stroke statistics - 2011 update: a report from the American Heart Association. Circulation 2011; 123:e18-e209.

4. Lemieux I, Pascot A, Couillard C, Lamarche B, Tchernof A, Almeras N, et al. Hypertriglyceridemic waist: a marker of the atherogenic metabolic triad (hyperinsulinemia; hyperapolipoprotein B; small dense LDL) in men? Circulation 2000; 102:179-84.

5. Lemieux I, Almeras N, Mauriege P, Blanchet C, Dewailly E, Bergeron J, et al. Prevalence of "hypertriglyceridemic waist" in men who participated in the Quebec Health Survey: association with atherogenic and diabetogenic metabolic risk fac tors. Can J Cardiol 2002; 18:725-32.
6. St-Pierre J, Lemieux I, Vohl MC, Perron P, Tremblay G, Despres JP, et al. Contribution of abdominal obesity and hypertriglyceridemia to impaired fasting glucose and coronary artery disease. Am J Cardiol 2002; 90:15-8.

7. Hiura Y, Acklin F, Newman J, Steinbeck K, Caterson ID, Mahajan D, et al. Hypertriglyceridemic waist as a screening tool for cardiovascular disease risk in indigenous Australian women. Ethn Dis 2003; 13:80-4.

8. Solati M, Ghanbarian A, Rahmani M, Sarbazi N, Allahverdian S, Azizi F. Cardiovascular risk factors in males with hypertriglycemic waist (Tehran Lipid and Glucose Study). Int J Obes Relat Metab Disord 2004; 28:706-9.

9. Esmaillzadeh A, Mirmiran P, Azizi F. Clustering of metabolic abnormalities in adolescents with the hypertriglyceridemic waist phenotype. Am J Clin Nutr 2006; 83:36-46.

10. Gazi IF, Filippatos TD, Tsimihodimos V, Saougos VG, Liberopoulos EN, Mikhailidis DP, et al. The hypertriglyceridemic waist phenotype is a predictor of elevated levels of small, dense LDL cholesterol. Lipids 2006; 41:647-54. 
11. Alavian SM, Motlagh ME, Ardalan G, Motaghian M, Davarpanah AH, Kelishadi R. Hypertriglyceridemic waist phenotype and associated lifestyle factors in a national population of youths: CASPIAN Study. J Trop Pediatr 2008; 54:169-77.

12. Esmaillzadeh A, Azadbakht L. Increased levels of inflammation among women with enlarged waist and elevated triglyceride concentrations. Ann Nutr Metab 2010; 57:77-84.

13. Gomez-Huelgas R, Bernal-Lopez MR, Villalobos A, Mancera-Romero J, Baca-Osorio AJ, Jansen S, et al. Hypertriglyceridemic waist: an alternative to the metabolic syndrome? Results of the IMAP Study (multidisciplinary intervention in primary care). Int J Obes (Lond) 2011; 35:292-9.

14. Arsenault BJ, Lemieux I, Despres JP, Wareham NJ, Kastelein JJ, Khaw KT, et al. The hypertriglyceridemic-waist phenotype and the risk of coronary artery disease: results from the EPIC-Norfolk prospective population study. CMAJ 2010; 182: 1427-32.

15. Esmaillzadeh A, Mirmiran P, Azizi F. Whole-grain intake and the prevalence of hypertriglyceridemic waist phenotype in Tehranian adults. Am J Clin Nutr 2005; 81:55-63.

16. Barros FC, Victora CG, Horta BL, Gigante DP. Methodology of the Pelotas birth cohort study from 1982 to 2004-5, Southern Brazil. Rev Saúde Pública 2008; 42 Suppl 2:7-15.

17. Rogowski O, Shapira I, Steinvil A, Berliner S. Lowgrade inflammation in individuals with the hypertriglyceridemic waist phenotype: another feature of the atherogenic dysmetabolism. Metabolism 2009; 58:661-7.

18. Horta BL, Gigante DP, Victora CG, Barros FC, Oliveira I, Silveira V. Early determinants of random blood glucose among adults of the 1982 birth cohort, Pelotas, Southern Brazil. Rev Saúde Pública 2008; 42 Suppl 2:93-100.

19. Craig CL, Marshall AL, Sjostrom M, Bauman AE, Booth ML, Ainsworth BE, et al. International physical activity questionnaire: 12-country reliability and validity. Med Sci Sports Exerc 2003; 35: 1381-95.

20. Thompson FE, Byers T. Dietary assessment resource manual. J Nutr 1994; 124(11 Suppl):2245S317 S.

21. Berenson GS, Srinivasan SR, Bao W, Newman 3rd WP, Tracy RE, Wattigney WA. Association between multiple cardiovascular risk factors and atherosclerosis in children and young adults. The Bogalusa Heart Study. N Engl J Med 1998; 338:1650-6.

22. Kung HC, Hoyert DL, Xu JQ, Murphy SL. Deaths: final data for 2005. Natl Vital Stat Rep 2008; 56: 1-120.

23. Kahn HS, Valdez R. Metabolic risks identified by the combination of enlarged waist and elevated triacylglycerol concentration. Am J Clin Nutr 2003; 78:928-34
24. LaMonte MJ, Ainsworth BE, DuBose KD, Grand jean PW, Davis PG, Yanowitz FG, et al. The hypertriglyceridemic waist phenotype among women. Atherosclerosis 2003; 171:123-30.

25. St-Pierre J, Lemieux I, Perron P, Brisson D, Santure M, Vohl MC, et al. Relation of the "hypertriglyceridemic waist" phenotype to earlier manifestations of coronary artery disease in patients with glucose intolerance and type 2 diabetes mellitus. Am J Cardiol 2007; 99:369-73.

26. Sam S, Haffner S, Davidson MH, D'Agostino RB, Feinstein S, Kondos G, et al. Hypertriglyceridemic waist phenotype predicts increased visceral fat in subjects with type 2 diabetes. Diabetes Care 2009; 32:1916-20.

27. de Graaf FR, Schuijf JD, Scholte AJ, Djaberi R, van Velzen JE, Roos CJ, et al. Usefulness of hypertriglyceridemic waist phenotype in type 2 diabetes mellitus to predict the presence of coronary artery disease as assessed by computed tomographic coronary angiography. Am J Cardiol 2010; 106: 1747-53.

28. Yu D, Huang J, Hu D, Chen J, Cao J, Li J. Is an appropriate cutoff of hypertriglyceridemic waist designated for type 2 diabetes among Chinese adults? Clin Nutr 2010; 29:192-8.

29. Amini M, Esmaillzadeh A, Sadeghi M, Mehvarifar $\mathrm{N}$, Zare $\mathrm{M}$. The association of hypertriglyceridemic waist phenotype with type 2 diabetes mellitus among individuals with first relative history of diabetes. J Res Med Sci 2011; 16:156-64.

30. Esmaillzadeh A, Mirmiran P, Azadbakht L, Azizi F Prevalence of the hypertriglyceridemic waist phenotype in Iranian adolescents. Amn J Prev Med 2006; 30:52-8.

31. Rosolova H, Petrlova B, Simon J, Sifalda P, Sipova I. High-sensitivity C-reactive protein and the hypertriglyceridemic waist in patients with type 2 diabetes and metabolic syndrome. Med Sci Monit 2008; 14:CR411-5.

32. Blackburn P, Lemieux I, Almeras N, Bergeron J, Cote M, Tremblay A, et al. The hypertriglyceridemic waist phenotype versus the National Cholesterol Education Program-Adult Treatment Panel III and International Diabetes Federation clinical criteria to identify high-risk men with an altered cardiometabolic risk profile. Metabolism 2009; 58: 1123-30.

33. Silveira VM, Horta BL, Gigante DP, Azevedo Junior MR. Metabolic syndrome in the 1982 Pelotas cohort: effect of contemporary lifestyle and socioeconomic status. Arq Bras Endocrinol Metab 2010; 54:390-7.

Submitted on 16/Apr/2012

Final version resubmitted on 22/Oct/2012

Approved on 06/Dec/2012 